DOI 10.22460/jpmi.v1i3.219-228

\title{
MENINGKATKAN DISPOSISI MATEMATIS SISWA SMP MENGGUNAKAN PENDEKATAN PEMBELAJARAN BERBASIS MASALAH
}

\author{
Dwi Candra Kusuma, M.Pd ${ }^{1}$, Risma Amelia, M.Pd. ${ }^{2}$ \\ 1,2 IKIP Siliwangi, Jl. Terusan Jenderal Sudirman, Cimahi, Jawa Barat, Indonesia \\ 1candra_dk87@yahoo.com, ${ }^{2}$ rismaamelia@ikipsiliwangi.ac.id
}

\begin{abstract}
Possible approach can improve student's mathematical disposition is problem-based learning, so that appear active and give a positive response to the learning of mathematics. Therefore, this study aims to find out how the improvement and achievement of mathematical disposition of junior high school students using a problem-based learning approach with a conventional approach. The research method used is quasi experiment. Population taken is a student of SMP Negeri in Purwakarta with sample of class VIIA and class VIIB. Instruments in this research is non-test instrument in the form of disposition scale and scale of student's view to problem based learning. Data analysis used is test of difference of two mean that is $t$ test, $t$ test and Mann Whitney test. The result of the research stated that the mathematical disposition of the students using the problem-based learning approach is better than the students using the conventional approach. While the students' view of problem-based learning shows sufficient criteria. Problem-based learning approaches should be used with careful planning as they require a relatively long time to perform.
\end{abstract}

Keywords: Mathematical Disposition, Problem Based Learning.

\begin{abstract}
Abstrak
Pendekatan yang berpeluang dapat meningkatkan disposisi matematis siswa adalah pembelajaran berbasis masalah, sehingga tampil aktif dan memberi respon yang positif terhadap pembelajaran matematika. Oleh karena itu, penelitian ini bertujuan untuk mengetahui bagaimana peningkatan dan pencapaian disposisi matematis siswa sekolah menengah pertama yang menggunakan pendekatan pembelajaran berbasis masalah dengan yang menggunakan pendekatan konvensional. Metode penelitian yang digunakan adalah kuasi eksperimen. Populasi yang diambil adalah siswa SMP Negeri di Purwakarta dengan sampel kelas VIIA dan kelas VIIB. Instrumen dalam penelitian ini adalah instrumen non-tes berupa skala disposisi dan skala pandangan siswa terhadap pembelajaran berbasis masalah.Analisis data yang digunakan adalah uji perbedaan dua rata-rata yaitu uji t, uji t' dan uji Mann Whitney. Hasil penelitian menyatakan bahwa disposisi matematis siswa yang pembelajarannya menggunakan pendekatan pembelajaran berbasis masalah lebih baik daripada siswa yang pembelajarannya menggunakan pendekatan konvensional. Sementara pandangan siswa terhadap pembelajaran berbasis masalah menunjukkan kriteria yang cukup. Pendekatan pembelajaran berbasis masalah sebaiknya digunakan dengan perencanaan yang matang karena memerlukan waktu yang relatif lama dalam pelaksanaannya.
\end{abstract}

Kata kunci: Disposisi Matematis, Pembelajaran Berbasis masalah.

How to cite: Kusuma, D. C., Ameila, R. (2018). Meningkatkan Disposisi Matematis Siswa SMP Menggunakan Pendekatan Pembelajaran Berbasis Masalah. JPMI - Jurnal Pembelajaran Matematika Inovatif, 1 (1), 45-52. 


\section{PENDAHULUAN}

Pendidikan merupakan usaha sadar dan terencana untuk mengembangkan segala potensi yang dimiliki oleh peserta didik melalui proses pembelajaran. Pendidikan bertujuan untuk mengembangkan potensi anak didik agar memiliki kekuatan spiritual, keagamaan, pengendalian diri, kepribadian, memiliki kecerdasan, berakhlak mulia serta memiliki keterampilan yang diperlukan sebagai anggota masyarakat. Pendidikan matematika pada jenjang pendidikan dasar mempunyai peranan yang sangat penting, sebab jenjang ini merupakan pondasi yang sangat menentukan dalam membentuk sikap, kecerdasan dan kepribadian anak.

Dalam pembelajaran matematika di kelas hampir selalu dilaksanakan secara konvensional. Akibatnya, siswa pada umumnya dapat melakukan berbagai perhitungan matematis, tetapi kurang menunjukkan hasil yang menggembirakan terkait penerapannya dalam kehidupan sehari-hari.

Berdasarkan apa yang penulis amati ketika mengajar, pada saat pembelajaran berlangsung sebagian siswa tidak memperhatikan penjelasan guru. Siswa juga tidak membaca buku-buku pelajaran dan tidak mengerjakan LKS kalau tidak diminta atau diperintahkan oleh guru. Berdasarkan pengalaman peneliti ketika guru memberikan pekerjaan rumah, siswa tidak mengerjakannya di rumah. Mereka cenderung mengerjakan pekerjaan rumah di sekolah dan mengandalkan jawaban teman. Siswa tidak berani mengemukakan pendapatnya dan malas bertanya. Saat guru memberikan penugasan pada siswa untuk mempelajari materi selanjutnya, siswa tampak sekali tidak mempelajari materi yang ditugaskan. Ini menunjukkan siswa belum mempunyai keinginan dan kesadaran dalam belajar. Hasilnya siswa menjadi cepat bosan, kurang berkonsentrasi, tidak percaya diri dan kurang aktif dalam pembelajaran.Kondisi yang demikian menunjukkan kurangnya disposisi matematis siswa dalam pembelajaran matematika.

Pendekatan berpeluang yang sesuai untuk meningkatkan disposisi matematis adalah pembelajaran berbasis masalah (PBM) .Jadi, PBM adalah suatu pendekatan pembelajaran yang menggunakan masalah dunia nyata sebagai suatu konteks bagi peserta didik untuk belajar tentang cara berpikir kritis dan keterampilan pemecahan masalah, serta untuk memperoleh pengetahuan dan konsep yang esensial dari materi pelajaran. NCTM (Sumarmo, 2013:203) mendefinisikan disposisi matematis sebagai ketertarikan dan apresiasi seseorang terhadap matematika.Dalam arti yang lebih luas, disposisi matematis bukan hanya sebagai sikap saja tetapi juga sebagai kecenderungan untuk berfikir dan bertindak positif.

Landasan teori PBM adalah kolaborativisme, suatu pandangan yang berpendapat bahwa siswa akan menyusun pengetahuan dengan cara membangun penalaran dari semua pengetahuan yang sudah dimilikinya dan dari semua yang diperoleh sebagai hasil kegiatan berinteraksi dengan sesama individu. Menurut paham konstruktivisme, manusia hanya dapat memahami melalui segala sesuatu yang dikonstruksinya sendiri.

Sears dan Hersh (Sumarmo, 2013:150) mengemukakan beberapa karakteristik PBM yaitu:

1. Masalah harus berkaitan dengan kurikulum

2. Masalah bersifat tak terstruktur, solusi tidak tunggal dan prosesnya bertahap

3. Siswa memecahkan masalah dan guru sebagai fasilitator

4. Siswa hanya diberi panduan untuk mengenali masalah dan tidak diberi formula untuk memecahkan masalah

5. Penilaian berbasis performa autentik 
Pierce dan Jones dalam Dasari (Sumarmo, 2013:150) mengklasifikasi PBM dalam dua level yaitu level rendah dan level tinggi. PBM tergolong pada level rendah jika hanya memuat sedikit karakteristik di atas dan PBM tergolong pada level tinggi jika siswa terlibat secara aktif dalam kegiatan-kegiatan yang mencerminkan karakteristik PBM di atas.

Apabila berbagai persyaratan dan ketrampilan pendidik serta pemelajar terpenuhi, PBM mempunyai berbagai potensi manfaat/kelebihan (Amir, 2009:27) yaitu:

1. Meningkatkan fokus pada pengetahuan yang relevan

2. Mendorong untuk berfikir

3. Membangun kerja tim, kepemimpinan, dan ketrampilan sosial

4. Membangun kecakapan belajar

5. Memotivasi pemelajar

Disamping kelebihannya, PBM memiliki beberapa kekurangan dalam pemanfaatannya, diantaranya adalah sebagai berikut:

1. Kurang terbiasanya peserta didik dan pengajar dengan metode ini

2. Kurangnya waktu pembelajaran

3. Siswa tidak dapat benar-benar tahu apa yang mungkin penting bagi mereka untuk belajar

4. Seorang guru sulit menjadi fasilitator yang baik

Penelitian ini bertujuan untuk menelaah disposisi matematis siswa yang pembelajarannya menggunakan PBM dibandingkan yang menggunakan pembelajaran biasa.

\section{METODE}

Metode yang digunakan dalam penelitian ini adalah metode kuasi eksperimen.Dalam penelitian terdapat dua kelompok, yaitu kelas kontrol dan kelas eksperimen. Kelas eksperimen mendapatkan perlakuan dengan pembelajaran berbasis masalah (PBM) dan kelas kontrol memperoleh pembelajaran biasa.Desain penelitiannya adalah sebagai berikut:

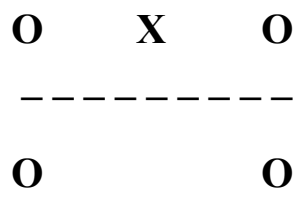

Keterangan:

O : $\quad$ Postes skala disposisi

X : Perlakuan dengan menggunakan PBM

_ _ _ : Pengambilan sampel tidak acak

Skala disposisi dan skala pandangan siswa terhadap pembelajaran diberikan kepada siswa sesudah kegiatan pembelajaran. Skala disposisi terdiri atas 25 butir kegiatan/pendapat/perasaan dengan empat pilihan jawaban, yaitu sangat sering (SS), sering (S), jarang (J) dan sangat jarang (SJ). Masing-masing pilihan jawaban dikaitkan dengan suatu nilai tertentu. Untuk mendukung kegiatan yang positif masing-masing mempunyai nilai $\mathrm{SS}=4, \mathrm{~S}=3, \mathrm{~J}=2, \mathrm{SJ}=1$ dan sebaliknya, untuk mendukung kegiatan yang negatif masing-masing mempunyai nilai $\mathrm{SS}=1, \mathrm{~S}=2, \mathrm{~J}=3$ dan $\mathrm{SJ}=4$. Bobot penilaian dalam angket dapat dilihat pada tabel berikut: 
Tabel 1

Bobot Nilai Angket Disposisi Matematis

No Pernyataan

Bobot Pernyataan

\begin{tabular}{llll}
\cline { 3 - 3 } & & Positif & Negatif \\
\hline 1 & Sangat Sering & 4 & 1 \\
\hline 2 & Sering & 3 & 2 \\
\hline 3 & Jarang & 2 & 3 \\
\hline 4 & Sangat Jarang & 1 & 4
\end{tabular}

Skala pandangan siswa terhadap pembelajaran diberikan kepada siswa sesudah kegiatan pembelajaran. Skala pandangan siswa mengenai pembelajaran dengan pendekatan PBM terdiri dari 30 butir pernyataan dengan empat pilihan jawaban yaitu sangat setuju (SS), setuju (S), tidak setuju (TS) dan sangat tidak setuju (STS). Untuk mendukung pernyataan pandangan positif masing-masing mempunyai nilai $\mathrm{SS}=4, \mathrm{~S}=3, \mathrm{TS}=2, \mathrm{STS}=1$ dan sebaliknya, untuk mendukung pernyataan negatif masing-masing mempunyai nilai $\mathrm{SS}=1, \mathrm{~S}=2, \mathrm{TS}=3$ dan $\mathrm{STS}=4$. Bobot penilaian dalam angket dapat dilihat pada tabel berikut:

Tabel 2

Bobot Nilai Angket Pandangan terhadap PBM

\begin{tabular}{llcc}
\hline \multirow{2}{*}{ No } & \multirow{2}{*}{ Pernyataan } & \multicolumn{2}{c|}{ Bobot Pernyataan } \\
\cline { 2 - 4 } & & Positif & Negatif \\
\hline 1 & Sangat Setuju & 4 & 1 \\
\hline 2 & Setuju & 3 & 2 \\
\hline 3 & Tidak Setuju & 2 & 3 \\
\hline 4 & Sangat Tidak Setuju & 1 & 4 \\
\hline
\end{tabular}

\section{HASIL DAN PEMBAHASAN}

Berdasarkan hasil pengolahan postes disposisi matematis, berikut ini disajikan deskripsi statistik hasil skor postes pada kelas PBM dan kelas konvensional dengan keterangan sebagai berikut:

Tabel 3

Statistik Deskriptif Hasil Skor DisposisiMatematis

\begin{tabular}{|c|c|c|c|c|c|c|}
\hline \multirow[t]{2}{*}{ Variabel } & \multirow[t]{2}{*}{ SMI } & \multirow[t]{2}{*}{ Statistik } & \multicolumn{2}{|c|}{$\begin{array}{c}\text { Pembelajaran } \\
\text { Berbasis } \\
\text { Masalah } \\
\text { (PBM) }\end{array}$} & \multicolumn{2}{|c|}{$\begin{array}{l}\text { Pembelajaran } \\
\text { Konvensional }\end{array}$} \\
\hline & & & $\begin{array}{l}\text { Pos } \\
\text { Tes }\end{array}$ & $\mathbf{n}$ & $\begin{array}{l}\text { Pos } \\
\text { Tes }\end{array}$ & $\mathbf{n}$ \\
\hline \multirow{2}{*}{ DM } & \multirow{2}{*}{100} & $\overline{\bar{x}}$ & 67,83 & \multirow{2}{*}{30} & 58,07 & \multirow{2}{*}{30} \\
\hline & & $\mathrm{SD}$ & 2,17 & & 2,12 & \\
\hline \multirow[t]{2}{*}{ PBM } & \multirow[t]{2}{*}{120} & $\overline{\boldsymbol{x}}$ & $\begin{array}{c}81,10 \\
(67,58 \%) \\
\end{array}$ & \multirow[t]{2}{*}{30} & & \multirow[t]{2}{*}{30} \\
\hline & & SD & 10,51 & & & \\
\hline
\end{tabular}


Keterangan:

DM : Disposisi Matematis

PBM : Pandangan terhadap Pembelajaran Berbasis Masalah

Perhitungan statistika dalam analisis ini menggunakan Microsoft Excel 2010, Software Minitab 16 dan SPSS 20 dengan tingkat kepercayaan 95\%. Analisa terhadap data disposisi matematis menggunakan uji t, tetapi sebelumnya diuji normalitas dan homogenitas varians. Untuk uji normalitas distribusi data menggunakan uji Kolmogorov-Sminorv, sedangkan uji homogenitas varians menggunakan uji $\mathrm{F}$ dengan taraf signifikansi 5\%. Pada pengujian normalitas skala disposisi matematis siswa kelas eksperimen dan kelas kontrol dihitung menggunakan uji Kolmogorov-Sminorv. Adapun hipotesis penelitiannya dirumuskan sebagai berikut:

$\mathrm{H}_{0}$ : Sampel berasal dari populasi yang berdistribusi normal.

$\mathrm{H}_{1}$ : Sampel berasal dari populasi yang tidak berdistribusi normal.

Kriteria pengujiannya adalah:

Jika $\mathrm{P} \geq 0,05$ maka $\mathrm{H}_{0}$ diterima

Jika $\mathrm{P}<0,05$ maka $\mathrm{H}_{0}$ ditolak

Berikut adalah hasil analisis uji normalitas yang telah dilakukan disajikan pada Gambar 1 dan Gambar 2.

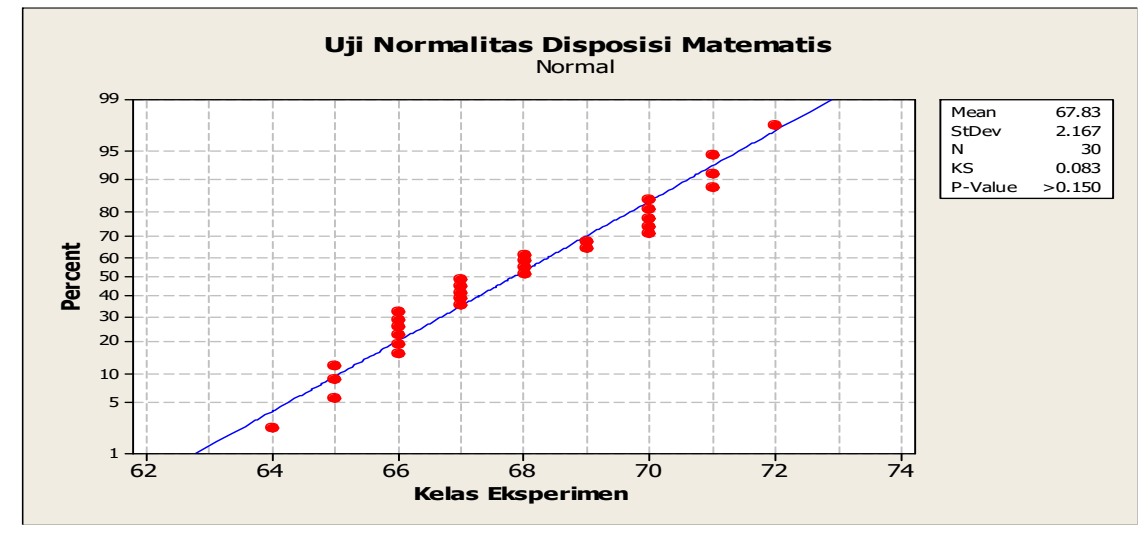

Gambar 1

Uji Normalitas Data Skala Disposisi Matematis Kelas Pembelajaran Berbasis Masalah

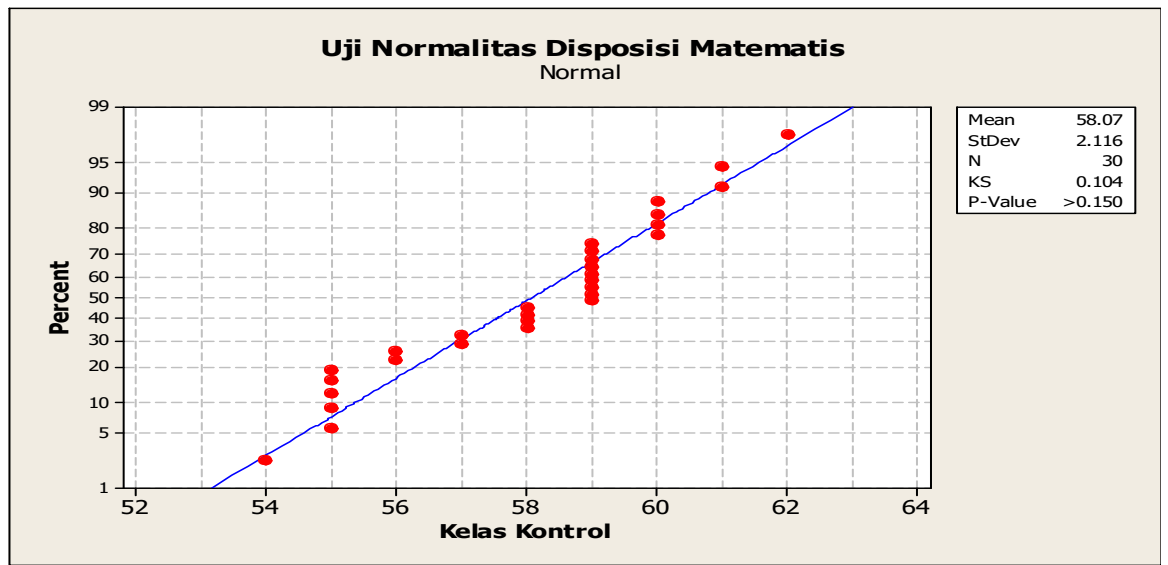

Gambar 2

Uji Normalitas Data Skala Disposisi Matematis Kelas Konvensional 
Berdasarkan Gambar 1 dan Gambar 2 terlihat bahwaberdasarkan kriteria kelas eksperimen maupun kelas kontrol memiliki nilai $P \geq 0,05$. Hal ini menandakan bahwa kedua sampel berdistribusi normal.

Karena data kedua kelas tersebut berdistribusi normal maka pengujian dilanjutkan dengan uji homogenitas varians kedua kelas dengan menggunakan uji Fdengan taraf signifikansi 5\%.

Hipotesis yang digunakan pada uji homogenitas varians adalah sebagai berikut:

$\mathrm{H}_{0}: \sigma_{1}^{2}=\sigma_{2}^{2}$ : Varians populasi data kedua kelas homogen

$\mathrm{H}_{1}: \sigma_{1}^{2} \neq \sigma_{2}^{2}:$ Varians populasi data kedua kelas tidak homogen

Keterangan:

$\sigma_{1}^{2}=$ Varians populasi data kelas PBM

$\sigma_{2}^{2}=$ Varians populasi data kelas konvensional

Kriteria pengujiannya sebagai berikut :

Jika nilai $\mathrm{P} \geq 0,05$ maka $\mathrm{H}_{0}$ diterima

Jika nilai $\mathrm{P}<0,05$ maka $\mathrm{H}_{0}$ ditolak

Berikut adalah hasil uji homogenitas varians yang telah dilakukan seperti tersaji pada Gambar 3.

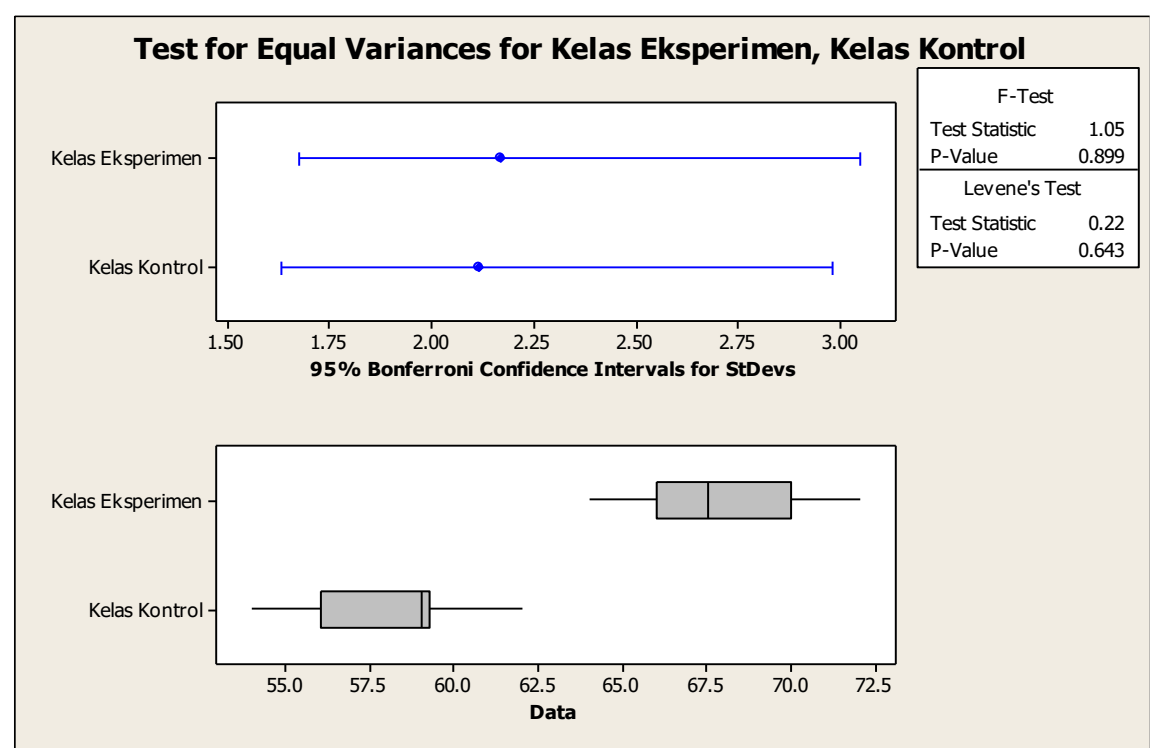

Gambar 3

Uji Homogenitas Varians Data Skala Disposisi Matematis

Dari Gambar 3 terlihat bahwa nilai $P \geq 0,05$ yang mengakibatkan kedua kelompok memiliki varians yang sama atau homogen.

Oleh karena kedua kelompok memiliki varians yang sama maka untuk menguji signifikansi perbedaan dua rata-rata digunakan uji t. Hipotesis pengujiannya sebagai berikut:

$\mathrm{H}_{0}: \mu_{1}=\mu_{2}$

Tidak terdapat perbedaan disposisi matematis secara signifikan antara siswa yang pembelajarannya menggunakan pendekatan PBM dengan siswa yang pembelajarannya menggunakan pendekatan konvensional.

$\mathrm{H}_{1}: \mu_{1}>\mu_{2}$ 
Disposisi matematis siswa yang pembelajarannya menggunakan pendekatan PBM secara signifikan lebih baik daripada siswa yang pembelajarannya menggunakan pendekatan konvensional.

Keterangan:

$\mu_{1}=$ Rata-rata disposisi matematis kelas PBM

$\mu_{2}=$ Rata-rata disposisi matematis kelas konvensional

Kriteria pengujian:

Jika $P \geq 0,05$ maka $\mathrm{H}_{0}$ diterima

Jika $P<0,05$ maka $\mathrm{H}_{0}$ ditolak

Hasil uji perbedaan rata-rata dengan menggunakan Software Minitab 16 dan mendapatkan output sebagai berikut:

Two-Sample T-Test and CI: Kelas Eksperimen, Kelas Kontrol

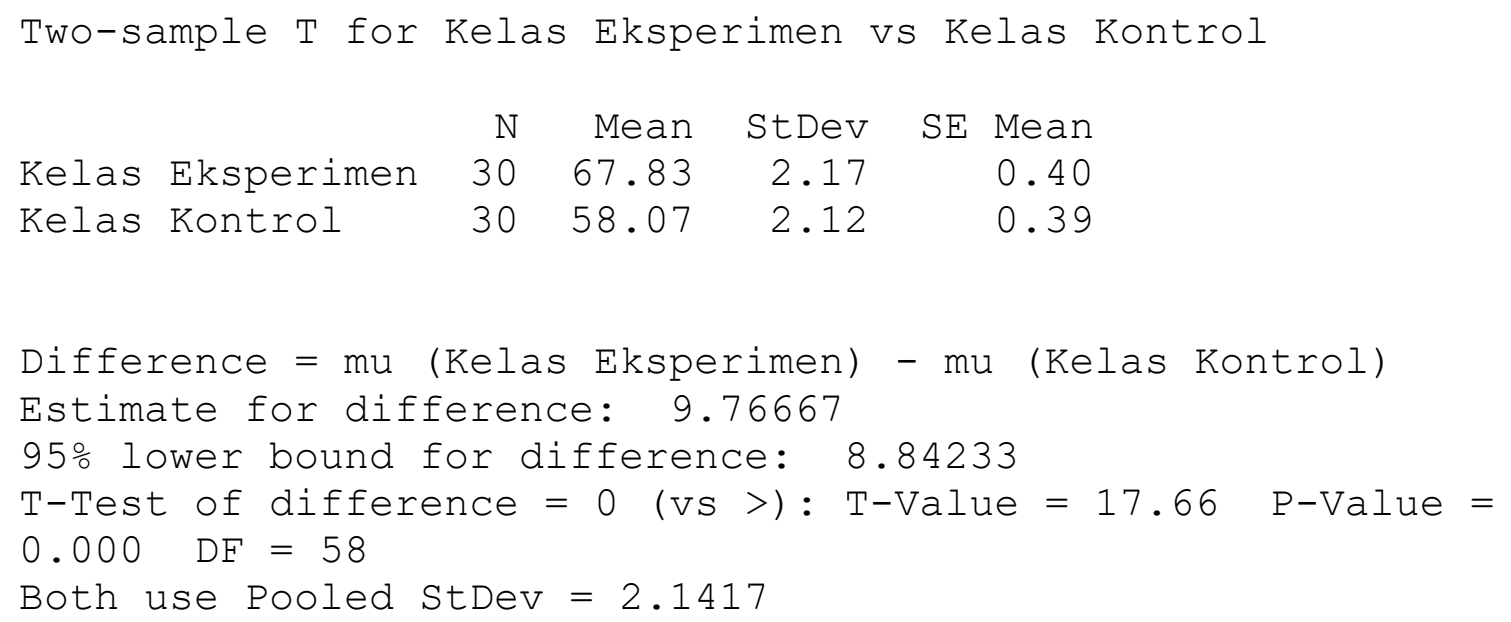

Berdasarkan hasil output terlihat bahwa nilai $P<0,05$ yang berarti hipotesis nol ditolak. Dengan demikian, disimpulkan bahwa disposisi matematis siswa yang pembelajarannya menggunakan pendekatan PBM lebih baik daripada disposisi matematis siswa yang pembelajarannya menggunakan pendekatan konvensional.

\section{KESIMPULAN}

Disposisi matematis siswa yang pembelajarannya menggunakan PBM lebih baik daripada siswa yang menggunakan pembelajaran konvensional.

\section{DAFTAR PUSTAKA}

Amir, M.T. (2008).Inovasi Pendidikan Melalui Peoblem Based Learning. Jakarta: Kencana Prenada Media Group.

Hendriana, H., Sumarmo, U. (2014). Penilaian Pembelajaran Matematika. Bandung: Refika Aditama.

Herman, T. (2007).Pembelajaran Matematika Berbasis Masalah untuk Meningkatkan Kemampuan Berpikir Matematik Tingkat Tinggi Siswa Sekolah Menengah Pertama.[Online]. Tersedia: 
http://file.upi.edu/Direktori/JURNAL/EDUCATIONIST/Vol._I_No._1Januari_2007/6. Tatang_Herman.pdf[17 Juli 2017]

Lidinillah, A.M. (2014). Konsep Dasar Pembelajaran Berbasis Masalah (PBM) atau Problem Based Learning.(PBL).[Online]. Tersedia:

http://file.upi.edu/Direktori/KDTASIKMALAYA/DINDIN_ABDUL_MUIZ_LIDINI LLAH_(KD-TASIKMALAYA)-19790[29 Agustus 2017]

Permana, Y., Sumarmo, U. (2007). "Mengembangkan Kemampuan Penalaran dan Koneksi Matematik Siswa SMA melalui Pembelajaran Berbasis Masalah". Kumpulan Makalah Berpikir dan Disposisi Matematik serta Pembelajarannya.Universitas Pendidikan Indonesia.147-158.

Ruseffendi, E.T. (1993). Statistika Dasar untuk Penelitian Pendidikan. Departemen Pendidikan dan kebudayaan Direktorat Jenderal Pendidikan Tinggi Proyek Pembinaan Tenaga Kependidikan Pendidikan Tinggi: tidak diterbitkan.

Ruseffendi, E.T (2006). Pengantar kepada Membantu Gutu Mengembangkan Kompetensinya dalam Meningkatkan Matematika dalam CBSA. Bandung: Tarsito.

Rusmono (2012). Strategi Pembelajaran dengan Problem Based Learning itu Perlu. Jakarta: Ghalia Indonesia.

Sudjana (2005). Metode Statistika. Bandung: Tarsito.

Sugiyono (1990).Metode Penelitian Pendidikan. Bandung: Alfabeta.

Suherman, E. (1990). Petunjuk Praktis untuk Melaksanakan Evaluasi Pendidikan Matematika. Bandung: Wijaya Kusumah.

Sumarmo, U. (2004). "Pembelajaran Matematika untuk Mendukung Pelaksanaan Kurikulum Berbasis Kompetensi”.Kumpulan Makalah Berpikir dan Disposisi Matematik serta Pembelajarannya.Universitas Pendidikan Indonesia.25-48.

Sumarmo, U. (2012). "Proses Berpikir Matematik: Apa dan Mengapa Dikembangkan". Kumpulan Makalah Berpikir dan Disposisi Matematik serta Pembelajarannya.Universitas Pendidikan Indonesia.429-485.

Sumarmo, U., Hidayat, W., Zulkarnaen, R., Hamidah, Sariningsih, R. (2012). “Kemampuan dan Disposisi Berpikir Logis, Kritis, dan Kreatif Matematik: Eksperimen terhadap siswa SMA menggunakan Pembelajaran Berbasis Masalah dan Strategi Talk-ThinkWrite". Kumpulan Makalah Berpikir dan Disposisi Matematik serta Pembelajarannya.Universitas Pendidikan Indonesia.371-392.

Sumarmo, U. (2013). "Evaluasi dalam Pembelajaran Matematika".Kumpulan Makalah Berpikir dan Disposisi Matematik serta Pembelajarannya.Universitas Pendidikan Indonesia.189-214.

Tasdikin (2012). Pembelajaran Berbasis Masalah untuk Meningkatkan kemampuan Komunikasi dan Pemecahan Masalah Matematis Siswa. S2 thesis, Universitas Pendidikan Indonesia.[Online]. Tersedia: http://repository.upi.edu/id/eprint/10445[17 Agustus 2017] 